\title{
Model Permintaan Ekspor Udang Segar Indonesia oleh Pasar Jepang, Amerika Serikat, dan Uni Eropa
}

\author{
[Indonesian Fresh Shrimp Export Demand Model by Japan, \\ United States of America, and European Union Markets]
}

\author{
Asnawi ${ }^{1}$, Estu Sri Luhur ${ }^{2}$, Siti Hajar Suryawati ${ }^{2}$, Freshty Yulia Arthatiani ${ }^{2}$ \\ ${ }^{1}$ Politeknik Ahli Usaha Perikanan \\ JI. Aup Bar. JI. Raya Pasar Minggu, Kota Jakarta Selatan, DKI Jakarta 12520, Indonesia. \\ ${ }^{2}$ Balai Besar Riset Sosial Ekonomi Kelautan dan Perikanan \\ Gedung BRSMD KP I Lt.4, Jalan Pasir Putih Nomor 1 Ancol Timur, Jakarta Utara, Indonesia.
}

\begin{abstract}
Abstrak
Tujuan dari kajian ini adalah untuk menganalisis faktor-faktor yang mempengaruhi permintaan ekspor udang Indonesia dan menganalisis respon jangka pendek dan jangka panjang terhadap ekspor udang Indonesia di pasar internasional. Kajian perlu dilakukan untuk menganalisis fenomena kinerja ekspor produk udang yang menunjukkan tren menurun dalam beberapa tahun terakhir. Pasar tujuan ekspor yang dianalisis adalah tiga pasar utama bagi ekspor komoditas udang Indonesia, yaitu Jepang, Amerika Serikat, dan Uni Eropa. Kajian ini menggunakan data runut waktu (time series) dari tahun 1985-2017. Berdasarkan hasil kajian menunjukkan bahwa Model Ekspor Udang Segar Indonesia memberikan hasil cukup baik dilihat dari segi ekonomi maupun statistik. Peubah yang masuk dalam persamaan di antaranya adalah variabel harga domestik, harga dunia, memenuhi kriteria ekonomi. Fungsi ekspor udang dipengaruhi harga udang domestik, harga ekspor udang ke negara tujuan, lag ekspor udang segar ke negara tujuan, nilai produk domestik bruto negara tujuan, tarif impor udang ke negara tujuan dan produksi udang domestik.
\end{abstract}

Kata Kunci: model ekspor; udang segar; negara tujuan ekspor; ECM

\section{Abstract}

The purpose of the study is to analyze the influencing factors of Indonesia's shrimp export demand and analyze the short-term and long-term response to Indonesian shrimp exports in the international market. A study needs to be conducted to analyze the phenomenon of shrimp product export performance which shows a declining trend in recent years. The analyzed markets are three main markets for Indonesian shrimp commodity exports, namely Japan, United States of America, and the European Union. This study used time series data from 1985-2017. Based on the results of the study shows that the Indonesian Fresh Shrimp Export model of provides quite good results in terms of economic and statistical. Variable included in the equation include domestic price variables, world prices, according economic criteria. Shrimp export function is influenced by domestic shrimp prices, shrimp prices to destination countries, lag of fresh shrimp exports to destination countries, the value of gross domestic product of the destination country, shrimp import tariffs to destination countries and domestic shrimp production.

Keywords: export model; fresh shrimp; export destination country; ECM

Penulis Korespondensi

Asnawi | asnawisaman62@gmail.com 


\section{PENDAHULUAN}

Udang merupakan primadona komoditas perikanan Indonesia karena potensi sumber daya komoditas tersebut cukup besar, nilai jualnya tinggi, dan peluang pasarnya sangat baik. Udang juga memiliki permintaan yang tinggi, baik di dalam maupun di luar negeri (Putri, Affandi, dan Sayekti 2020). Sumber produksi udang di Indonesia berasal dari hasil penangkapan di laut dan perairan umum daratan serta hasil budidaya di tambak-tambak (Ihsan dan Tajuddin 2019). Berdasarkan data Kementerian Kelautan dan Perikanan (2020) dan BPS (2019), volume produksi udang Indonesia pada tahun 2019 sebanyak 1,09 juta ton yang diperoleh dari kegiatan penangkapan sebanyak 0,23 juta ton dan 0,86 juta ton dari kegiatan budidaya.

Udang merupakan salah satu dari 10 komoditas utama yang memberikan kontribusi paling besar dalam hal penerimaan devisa negara dari sub sektor perikanan (Pudyastuti, Sambodo, dan Windhani 2018). Pada tahun 2019, kontribusi devisa negara dari ekspor udang sebesar 34,83\% atau setara dengan USD 1,72 miliar. Sumbangan devisa dari ekspor udang ini tercatat lebih rendah dibandingkan tahun 2018 yang mampu menyumbang devisa sebesar $35,84 \%$ atau senilai USD 1,74 miliar. Hal ini disebabkan oleh harga ekspor komoditas udang Indonesia turun di pasar dunia sebesar 6,2\%. Produk perdagangan komoditas udang dunia dibagi menjadi udang segar beku dan olahan. Udang segar merupakan bahan baku udang beku dan udang beku merupakan bahan baku untuk udang olahan (Rizqy 2020). Volume ekspor udang Indonesia ke pasar dunia pada tahun 2019 didominasi oleh udang beku sebanyak 0,15 juta ton, sedangkan ekspor udang olahan dan udang segar masing-masing sebanyak 0,05 juta ton dan 0,01 juta ton (UN Comtrade 2020).

Sejak tahun 1980-an, Indonesia menjadi negara pengekspor udang ke beberapa negara di dunia di antaranya Jepang, Amerika Serikat, Cina, dan Uni Eropa sebagai pasar utama produk udang Indonesia. Pada tahun 2019, keempat negara tersebut menyerap lebih dari $89,67 \%$ dari total volume ekspor produk udang Indonesia. Dari sisi nilai, impor udang keempat negara tersebut mencapai 93,39\% atau sebesar USD 1,6 miliar dari total nilai ekspor udang Indonesia (Rizqy 2020). Namun demikian, Indonesia selalu menempati posisi empat besar sebagai negara eksportir udang setelah Vietnam, India, dan Thailand (Yulistiani 2019). Hambatan non tarif pada ekspor produk udang Indonesia pada pasar utama menyebabkan rendahnya daya saing dibandingkan negara-negara pesaing tersebut (Permatasari 2019). 
Beberapa studi empiris menduga konsumsi ikan masyarakat global akan semakin meningkat karena jumlah penduduk dan pendapatan yang terus meningkat serta adanya pergeseran pola makan sehat dari daging merah (red meat) ke daging putih (white meat) makin meningkat (Hidayati, Darwanto, dan Masyhuri 2017). Hal ini sejalan dengan kinerja volume ekspor produk udang Indonesia yang tumbuh rata-rata 5,6\% selama periode 2015-2019. Nilai ekspor pada periode yang sama tumbuh sebesar 3,7\% (KKP 2020). Namun demikian, FAO (2018) menunjukkan pertumbuhan volume ekspor udang Indonesia memiliki angka penurunan yang cukup besar dibanding negara-negara eksportir lainnya yang sebagian besar mengalami peningkatan volume ekspor. Kondisi ini menunjukkan kinerja ekspor udang Indonesia melambat karena produksi di dalam negeri yang juga menurun (Fatimah, Marwanti, dan Supardi 2020; Luhur, Asnawi, dan Suryawati 2020).

Kajian ini dilakukan untuk menganalisis faktor-faktor yang berpengaruh terhadap ekspor udang Indonesia serta menganalisis respon jangka pendek dan jangka panjang terhadap ekspor udang Indonesia di pasar internasional. Hasil kajian ini diharapkan dapat berkontribusi sebagai bahan masukan bagi pengambil kebijakan yang terkait dengan pengem- bangan budidaya dan kinerja ekspor komoditas udang Indonesia.

\section{BAHAN DAN METODE}

Komoditas udang merupakan komoditas perikanan yang penting dalam perekonomian Indonesia terutama dalam peningkatan ekspor dan menghasilkan devisa. Bahkan Indonesia merupakan negara produsen hasil perikanan terbesar di dunia setelah Cina. Namun demikian, keunggulan tersebut belum diikuti dengan kemampuan dalam meningkatkan nilai tambah dan memenuhi kecukupan konsumsi dalam negeri. Permasalahan yang terjadi adalah kinerja ekspor di sektor perikanan melambat dan untuk memenuhi kebutuhan bahan baku industri dan konsumsi dalam negeri, impor perikanan masih dilakukan. Berdasarkan hal tersebut maka kajian mengenai model ekspor udang yang merupakan komoditas unggulan perlu dilakukan. Kajian yang dilakukan fokus pada analisis kinerja ekspor udang yang sangat bermanfaat dalam pengembangan budidaya udang bagi pengambil kebijakan dan pembudidaya.

\section{Waktu Penelitian}

Penelitian ini dilaksanakan pada bulan Januari sampai dengan Desember 2018. 


\section{Jenis dan Sumber Data}

Data yang digunakan dalam penelitian ini adalah data sekunder. Data sekunder yang digunakan berupa data runut waktu (time series) selama 29 tahun terakhir, yaitu sejak 1989 sampai dengan 2017. Data sekunder diperoleh dari berbagai instansi terkait seperti Badan Pusat Statistik (BPS), Kementerian Kelautan dan Perikanan (KKP), Kementerian Perindustrian, Kementerian Perdagangan, Asosiasi Perikanan, dan hasil penelitian terkait.

\section{Metode Analisis Data}

\section{Metode ECM}

Variabel dependen dan independen dapat memiliki kointegrasi atau hubungan keseimbangan jangka panjang, namun dalam jangka pendek mungkin terdapat ketidakseimbangan yang sering terlihat dalam perilaku ekonomi. Hal ini bermakna bahwa yang diinginkan oleh pelaku ekonomi belum tentu sama dengan keadaan sebenarnya sehingga diperlukan suatu penyesuaian (adjustment) untuk melakukan koreksi terhadap adanya perbedaan ini. Model yang dapat digunakan untuk memasukkan penyesuaian untuk melakukan koreksi bagi ketidakseimbangan disebut sebagai model koreksi kesalahan (Error Correction Model - ECM). Pendekatan ini muncul sejak para ahli ekonometrika membahas secara khusus terkait masalah data runut waktu. Model ECM pertama kali diperkenalkan oleh Sargan dan kemudian dikembangkan oleh Hendry dan juga Engle-Granger (Granger dan Newbold 1974). Model ECM memiliki beberapa kegunaan dalam mengatasi masalah data time series yang tidak stasioner dan masalah regresi lancung (spurious) (Nyatanga 2017).

Model ECM mengumpamakan terdapat hubungan jangka panjang atau keseimbangan antara dua variabel $X$ dan $Y$ sebagai berikut (1):

$$
Y_{t}=\beta_{0}+\beta_{1} X_{t}
$$

Jika $Y$ berada pada titik keseimbangan terhadap $X$ maka keseimbangan antara dua variabel $X$ dan $Y$ pada persamaan (1) di atas dapat terpenuhi. Namun, dalam sistem ekonomi pada umumnya, keseimbangan variabel-variabel ekonomi jarang sekali diperoleh. Bila $Y_{t}$ memiliki nilai yang berbeda dengan nilai keseimbangannya maka perbedaan sisi kiri dan kanan pada persamaan (2) sebesar:

$$
E C_{t}=Y_{t}-\beta_{0}-\beta_{1} X_{t}
$$

Nilai perbedaan $E C_{t}$ ini dapat disebut sebagai kesalahan ketidakseimbangan (disequilibrium error). Oleh karena itu, jika $E C_{t}=0$ maka $Y$ dan $X$ berada pada kondisi keseimbangan. Karena $Y$ dan $X$ sangat jarang berada pada kondisi keseimbangan maka perlu melakukan observasi hubungan ketidakseimbangan (hubungan jangka pendek) dengan 
memasukkan unsur kelambanan $\mathrm{Y}$ dan $\mathrm{X}$ (3).

$$
\begin{gathered}
Y_{t}=b_{0}+b_{1} X_{t}+b_{2} X_{t-1}+\phi Y_{t-1}+e_{t} \\
\text { di mana } 0<\phi<1
\end{gathered}
$$

Dalam persamaan (3) dimasukkan kelambanan tingkat pertama (first order lags), tetapi dapat juga dimasukkan kelambanan pada tingkat dua atau yang lebih tinggi. Pada persamaan (3), nilai $Y$ memerlukan waktu untuk melakukan penyesuaian secara penuh terhadap variasi $X$. Kondisi ini juga konsisten dengan ide bahwa $Y$ tidak selalu dalam kondisi keseimbangan terhadap variabel $X$. Jika nilai $b_{2}=0$ maka persamaan (3) menjadi model penyesuaian parsial (Partial Adjusment Model - PAM).

Permasalahan dalam mengestimasi persamaan (3) adalah jika data tidak stasioner pada tingkat level. Untuk mengatasi masalah ini maka persamaan (3) perlu diubah dengan cara mengurangi setiap sisi dengan $Y_{t-1}$ sehingga menjadi persamaan (4):

$$
\begin{gathered}
Y_{t}-Y_{t-1}=b_{0}+b_{1} X_{t}+b_{2} X_{t-1}+\phi Y_{t-1}-Y_{t-1}+e_{t} \\
Y_{t}-Y_{t-1}=b_{0}+b_{1} X_{t}+b_{2} X_{t-1}-(1-\phi) Y_{t-1}+e_{t}
\end{gathered}
$$

Penambahan dan pengurangan dengan $b_{1} X_{t-1}$ di sisi kanan persamaan (4) akan menghasilkan persamaan (5) sebagai berikut:

$$
\begin{gathered}
Y_{t}-Y_{t-1}=b_{0}+b_{1} X_{t}-b_{1} X_{t-1}+b_{1} X_{t-1}+b_{2} X_{t-1}- \\
\quad(1-\phi) Y_{t-1}+e_{t} \\
\begin{array}{c}
\Delta Y_{t}=b_{0}+b_{1} \Delta X_{t}+\left(b_{1}+b_{2}\right) X_{t-1}-\lambda Y_{t-1}+e_{t}
\end{array}
\end{gathered}
$$

Di mana: $\Delta$ menunjukkan selisih antara $X_{t}$ dan $X_{t-1}$ dan $\lambda=1-\phi$.
Persamaan (5) dapat juga diubah bentuknya menjadi persamaan

sebagai berikut:

$$
\begin{gathered}
\Delta Y_{t}=b_{1} \Delta X_{t}-\lambda\left(Y_{t-1}-\beta_{0}-\beta_{1} X_{t-1}\right)+e_{t} \\
\text { di mana: } \beta_{1}=\left(b_{1}+b_{2}\right) / \lambda \text { dan } \beta_{0}=b_{0} / \lambda
\end{gathered}
$$

$$
\lambda\left(Y_{t-1}-\beta_{0}-\beta_{1} X_{t-1}\right) \text { pada }
$$

persamaan (6) dapat diinterpretasikan sebagai kesalahan ketidakseimbangan dari periode waktu sebelumnya ( $t-1)$. Persamaan tersebut menjelaskan bahwa perubahan $Y$ masa sekarang dipengaruhi oleh perubahan $X$ dan kesalahan ketidakseimbangan (error correction component) periode sebelumnya. Kesalahan ketidakseimbangan ini merupakan variabel gangguan periode sebelumnya yang merupakan model ECM tingkat pertama (first order error correction model). Pada persamaan (6), parameter $\lambda$ adalah parameter penyesuaian, parameter $b$ menjelaskan pengaruh jangka pendek dan parameter $\beta$ menjelaskan pengaruh jangka panjang.

Model ECM yang diturunkan tersebut dikenal dengan model dua langkah (two steps) dari Engle-Granger (E-G). Menurut E-G jika dua variabel $Y$ dan $X$ tidak stasioner, tetapi terkointegrasi maka hubungan antara keduanya dapat dijelaskan dengan model ECM sehingga persamaan (6) dapat ditulis menjadi persamaan (7) sebagai berikut:

$$
\Delta Y_{t}=\alpha_{0}+\alpha_{1} \Delta X_{t}+\alpha_{2} E C_{t}+e_{t}
$$


Di mana $\alpha_{1}$ adalah koefisien jangka pendek, koefisien koreksi ketidakseimbangan $\alpha_{2}$ dalam bentuk nilai absolut menjelaskan seberapa cepat waktu diperlukan untuk mendapatkan nilai keseimbangan. Adapun langkah-langkah dalam penyusunan model ECM adalah sebagai berikut.

\section{Spesifikasi Model}

Dalam kajian ini akan dilakukan analisis mengenai hal-hal yang memengaruhi ekspor udang segar ke tiga negara tujuan ekspor. Model ekonometrika yang digunakan merupakan modifikasi dari model Catao-Falcetti (Falcetti dan Catão 1999).

Fungsi permintaan ekspor produk udang Indonesia di pasar internasional dalam bentuk matematis sebagai berikut (8):

$$
\begin{gathered}
N X_{j t}=c_{0} P X_{j t}+c_{1} P D_{t}+c_{2} N T_{t}+c_{3} N Q_{t+} \\
c_{4} G D P K_{j t}+\varepsilon_{j t}
\end{gathered}
$$

Dengan cara penurunan model ECM maka persamaan (8) dapat ditulis menjadi (9):$$
\Delta N X_{j t}=\gamma_{1} \Delta P X_{j t}+\gamma_{2} \Delta P D_{t}+\gamma_{3} \Delta N T^{t}+\gamma_{4}
$$$$
\Delta N Q_{t}+\gamma_{5} \Delta G D P K_{j t}-\lambda_{2}\left(N X_{j t-1}-\delta_{0}-\delta_{1} P X_{j t-1}\right.
$$$$
\left.-\delta_{2} P D_{t-1}-\delta_{3} N T_{t-1}-\delta_{4} N Q_{t-1}-\delta_{5} G N P K_{j t-1}\right)+
$$$$
\text { dimana: }
$$$$
\varepsilon_{j t}
$$

$\mathrm{NX}_{\mathrm{jt}}$ : Nilai ekspor udang segar Indonesia (000 US \$)

$\mathrm{PX}_{\mathrm{jt}} \quad$ : Harga ekspor udang segar Indonesia (US $\$ / \mathrm{kg}$ )

$\mathrm{PD}_{\mathrm{t}} \quad$ : Harga domestik udang segar Indonesia (Rp/kg)

$\mathrm{NT}_{\mathrm{t}} \quad$ : Nilai Tukar nominal rupiah terhadap US dollar tahun $\mathrm{t}(\mathrm{Rp} / \mathrm{US} \$)$

NQt : Nilai Produksi komoditas udang Indonesia (Miliar Rupiah)
}

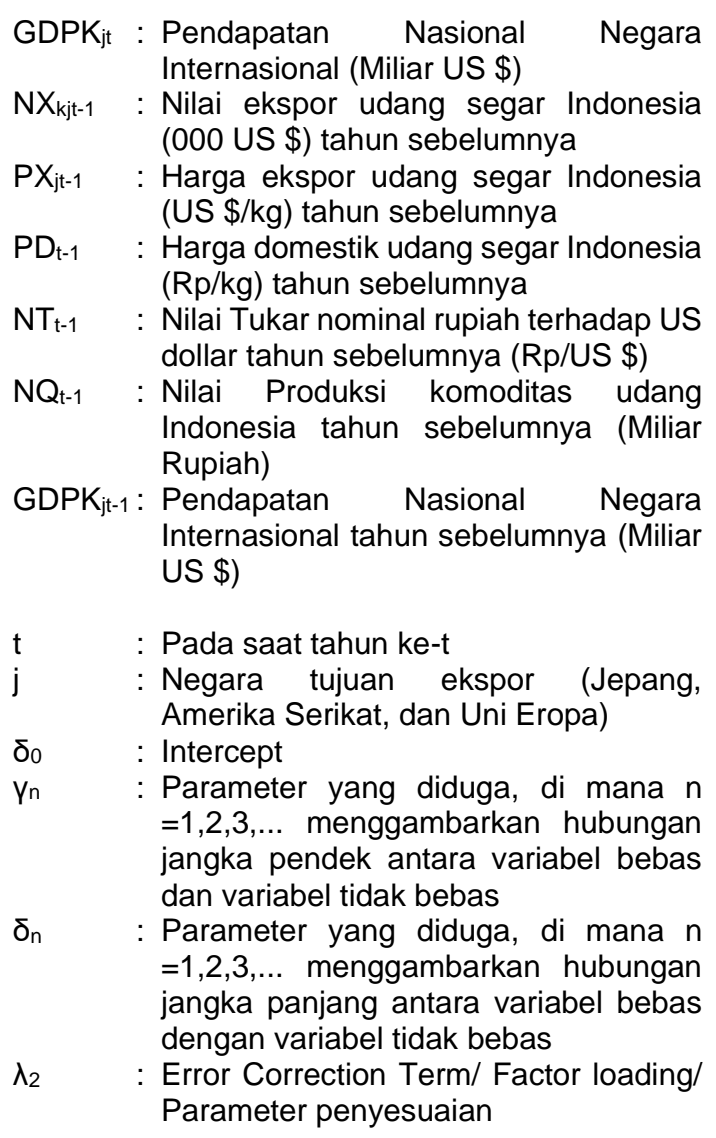

\section{Uji akar-akar unit}

Uji akar-akar unit digunakan untuk mengetahui apakah data runut waktu yang digunakan stasioner atau tidak. Uji ini digunakan untuk melihat apakah koefisien tertentu dari model autoregresif yang ditaksir memiliki nilai satu atau tidak (Rizal dan Akbar 2015). Jika koefisien tersebut memiliki nilai sama atau kurang dari satu maka data tersebut tidak stasioner. Langkah awal yang dilakukan dalam uji akar-akar unit adalah melakukan penaksiran model autoregresif dari masing-masing variabel yang digunakan dalam penelitian dengan OLS (persamaan 10 dan 11). 


$$
\begin{gathered}
D X_{t}=a_{0}+a_{1} B X_{t}+\sum_{i=1}^{k} b_{i} B_{i} D X_{t} \\
D X_{t}=c_{0}+c_{1} T+c_{2} B X_{t}+\sum_{i=1}^{k} d_{i} B_{i} D X_{t}
\end{gathered}
$$

di mana :

$D X_{t}=X_{t}-X_{t-1}$

$B X_{t}=X_{t-1}$,

$T=$ trend waktu; $X_{t}$ adalah variabel yang diamati pada periode $t$; dan $B$ adalah operasi kelambanan waktu.

Selanjutnya adalah menghitung nilai statistik DF (Dickey Fuller) dan ADF (Augmented Dickey Fuller). Nilai DF dan ADF untuk uji hipotesis bahwa $a_{1}=0$ dan $\mathrm{c}_{2}=0$ ditunjukkan oleh nilai $t$ pada koefisien regresi $B X_{t}$ pada persamaan (10) dan (11). Besarnya waktu kelambanan $k$ ditentukan oleh $k=N^{1 / 3}$ di mana $\mathrm{N}$ adalah banyaknya jumlah pengamatan.

\section{Model Koreksi Kesalahan}

Bila residual yang diperoleh dari estimasi persamaan jangka panjang pada model ekspor itu stasioner pada derajat integrasi $\mathrm{I}(0)$ maka dapat dipastikan bahwa variabel-variabel dalam persamaan tersebut terkointegrasi atau terdapat hubungan keseimbangan jangka panjang antar variabel meskipun dalam jangka pendek terjadi ketidakseimbangan (Susanawati et al. 2015; Widyawati dan Wahyudi 2016). Model koreksi kesalahan atau ECM merupakan model yang memasukkan penyesuaian untuk melakukan koreksi bagi tidak- seimbangan (Syahputra, Hamzah, dan Nasir 2017). Estimasi model koreksi kesalahan (ECM) dapat dilakukan lebih lanjut bila variabel-variabel itu terkointegrasi dan berada pada derajat integrasi yang sama. Dalam kajian ini digunakan model ECM dengan EngleGranger yang memiliki bentuk persamaan sebagai berikut (12):

$$
\Delta Y_{t}=\alpha_{0}+\alpha_{1} \Delta X_{t}+\alpha_{2} E C T_{t-1}+e_{t}
$$

Koefisien koreksi ketidakseimbangan $\alpha_{2}$ dalam bentuk nilai absolut menjelaskan seberapa cepat waktu yang diperlukan untuk mendapatkan nilai keseimbangan (Bass 2018; Rahmawati dan Hidayat 2017).

\section{HASIL DAN PEMBAHASAN}

\section{Permintaan Ekspor Udang Segar oleh Pasar Jepang}

Hasil estimasi Error Correction Model (ECM) permintaan ekspor udang segar oleh pasar Jepang (VXUSJ $J_{t}$ selama periode 1989-2017 sebagai fungsi dari harga udang domestik $\left(P \cup D_{t}\right)$, harga ekspor udang segar ke Jepang $\left(P X \cup S J_{t}\right)$, lag ekspor udang segar ke Jepang $\left(V X U S J_{t-1}\right)$, nilai produk domestik bruto Jepang $\left(G D P J_{t}\right)$, nilai tukar rupiah terhadap dolar $\left(N T_{t}\right)$, dan produksi udang domestik Indonesia $\left(V Q U D_{t}\right)$. Dengan demikian, persamaan permintaan ekspor udang segar Indonesia oleh pasar Jepang dalam jangka panjang dapat dirumuskan sebagai berikut: 


$$
\begin{aligned}
\operatorname{LNVXUSJ}_{t}= & a_{0}+a_{1} L N P U D_{t}+a_{2} L N P X U S J_{t}+ \\
& a_{3} L N V X U S J_{t-1}+a_{4} L N V Q U D_{t}+ \\
& a_{5} L N N T_{t}+a_{6} L N G D P J_{t}+e_{t}
\end{aligned}
$$

Persamaan untuk estimasi model dalam jangka pendek digunakan model error correction sebagai berikut:

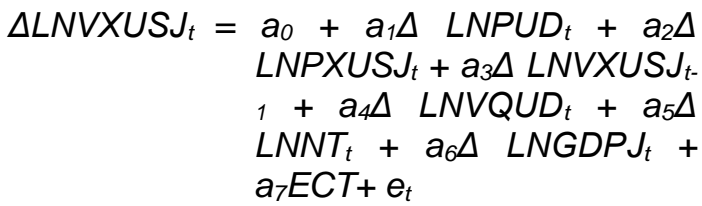

di mana $a_{1}<0, a_{2}>0, a_{3}>0, a_{4}>0, a_{5}>0, a_{6}>$ $0, a_{7}<0$

Keterangan:

LNVXUSJt: Log volume ekspor udang segar Indonesia di pasar Jepang pada tahun ke-t $(\mathrm{kg})$

LNPUD $_{t}$ : Log harga udang segar domestik Indonesia pada tahun $\mathrm{t}(\mathrm{Rp} / \mathrm{kg})$

LNPXUSJt: Log harga ekspor udang segar Indonesia di pasar Jepang pada tahun $\mathrm{t}$ (US $\$ / \mathrm{kg}$ )

LNVXUSJ $_{\mathrm{t}-1}$ : Log volume ekspor udang segar Indonesia di pasar Jepang pada tahun sebelumnya $\mathrm{t}-1 \mathrm{~kg})$

LNVQUD $_{t}$ : Log produksi udang domestik Indonesia pada tahun $\mathrm{t}(\mathrm{kg})$

$\mathrm{LNNT}_{\mathrm{t}} \quad$ : Log nilai tukar riil rupiah terhadap US dollar (Rp/US\$)

LNGDPJt $_{\mathrm{t}}$ : Log pendapatan nasional Jepang (US\$ Miliar)
Sebelum dilakukan analisis (pendugaan) terhadap persamaan yang digunakan dalam model, terlebih dahulu seluruh data yang digunakan harus berada pada kondisi yang stasioner. Hasil pengujian stasioner terhadap peubah-peubah yang digunakan dalam kajian ini tertera pada Tabel 1.

Hasil uji akar-akar unit menunjukkan bahwa pada kondisi level hampir semua variabel belum stasioner, baik dengan pendekatan Augmented Dickey Fuller (ADF) maupun Phillip-Peron (PP), kecuali variabel $L N P U D_{t}$ dan $L N P X U S J_{t}$. Akan tetapi, semua peubah telah stasioner pada kondisi first difference dengan tingkat kesalahan $1 \%$, baik dengan pendekatan ADF maupun PP. Dengan demikian, dapat disimpulkan bahwa semua peubah ini dapat digunakan lebih lanjut ke persamaan permintaan ekspor udang segar Indonesia di pasar Jepang dengan menggunakan

Tabel 1. Hasil Uji Akar-akar Unit

\begin{tabular}{llllc}
\hline \multirow{2}{*}{$\begin{array}{c}\text { Peubah/ } \\
\text { Variabel }\end{array}$} & \multicolumn{2}{c}{ Tingkat/Level } & \multicolumn{2}{c}{$\begin{array}{c}\text { Perbedaan Pertama/ First } \\
\text { Difference }\end{array}$} \\
\cline { 2 - 5 } & ADF & PP & ADF & PP \\
\hline LNVXUSJ $_{t}$ & 0,8122 & 0,4679 & $0,0001^{* * *}$ & $0,0000^{* * *}$ \\
LNPUD $_{t}$ & 0,6382 & $0,0066^{* * *}$ & $0,0000^{* * *}$ & $0,0001^{* * *}$ \\
LNPXUSJ $_{t}$ & $0,0022^{* * *}$ & $0,0029^{* * *}$ & $0,0002^{* * *}$ & $0,0000^{\star * *}$ \\
LNVQUD $_{t}$ & 0,8626 & 0,9459 & $0,0000^{* * *}$ & $0,0000^{\star * *}$ \\
LNGDPJ $_{t}$ & 0,3676 & 0,4238 & $0,0010^{* * *}$ & $0,0017^{* * *}$ \\
LNNT $_{t}$ & 0,1955 & 0,2096 & $0,0000^{* * *}$ & $0,0000^{\star * *}$ \\
LNVXTSJ $_{t-1}$ & 0,9860 & 0,7208 & $0,0001^{* * *}$ & $0,0000^{* * *}$ \\
\hline Keterangan: &
\end{tabular}


Tabel 2. Hasil Estimasi Permintaan Ekspor Udang Segar di Pasar Jepang

\begin{tabular}{|c|c|c|c|c|}
\hline Variabel & & $\begin{array}{l}\text { Koefisien } \\
\text { Regresi }\end{array}$ & $\begin{array}{c}\text { Simpangan } \\
\text { Baku }\end{array}$ & t-statistik \\
\hline Konstanta & & $-0,036162$ & 0,025166 & $-1,436964$ \\
\hline$D\left(L N P \cup D_{t}\right)$ & & $-0,235202^{\star *}$ & 0,105408 & $-2,231353$ \\
\hline$D\left(L N P X \cup S J_{t-1}\right)$ & & 0,008831 & 0,008521 & 1,036377 \\
\hline$D\left(L N V Q U D_{t-1}\right)$ & & $-0,077561$ & 0,121898 & $-0,636274$ \\
\hline$D\left(G D P J_{t-1}\right)$ & & $0,576129^{\star *}$ & 0,231273 & 2,491120 \\
\hline$D\left(L N N T_{t}\right)$ & & $0,678472^{* * *}$ & 0,145243 & 4,671303 \\
\hline$D\left(L N V X T S J_{t-1}\right)$ & & 0,164942 & 0,207150 & 0,796241 \\
\hline$E C T_{t-1}$ & & $-0,622095^{\star *}$ & 0,287951 & $-2,160420$ \\
\hline $\mathrm{R}^{2}$ & 0,727785 & $\operatorname{LM}(2)$ & 0,802437 & $($ prob $,=0,6695)$ \\
\hline $\mathrm{R}^{2}$-adjusted & 0,627495 & White & 5,775514 & $($ prob $,=0,5662)$ \\
\hline F-statistic & 7,256815 & $\mathrm{ARCH}$ & 0,328793 & $($ prob $,=0,5664)$ \\
\hline F-prob, & 0,000269 & Jarque-Berra & 0,842662 & $($ prob $,=0,6562)$ \\
\hline DW & 1,879494 & & & \\
\hline
\end{tabular}

Keterangan: ${ }^{* *}$ dan ${ }^{* * *}=$ Nyata pada taraf $\alpha=5 \%$, dan $\alpha=1 \%$

pendekatan Error Correction Model (ECM).

Hasil estimasi OLS ditunjukkan pada Tabel 2, di mana ekspor komoditas udang segar ke Jepang secara signifikan dipengaruhi nilai tukar rupiah terhadap US dollar $\left(N T_{t}\right)$ dengan level signifikan $\alpha=1 \%$, dipengaruhi harga udang domestik $\left(P U D_{t}\right)$ dan pendapatan domestik bruto Jepang tahun sebelumnya $\left(G D P J_{t-1}\right)$ dengan level signifikan $\alpha=5 \%$. Sementara itu, harga ekspor produk udang segar ke Jepang tahun sebelumnya $\left(P X \cup S J_{t-1}\right)$ tidak signifikan. Secara teori tanda sesuai dengan yang diharapkan.

Berdasarkan hasil pengujian asumsi klasik maka model permintaan yang dibangun dapat digunakan untuk mendapatkan hasil regresi yang efisien dan tidak bias. Dari Tabel 2, diperoleh hasil bahwa $R^{2}=0,7278$ yang menunjukkan bahwa variabel bebas mampu menjelaskan variasi dari variabel terkait sebesar $72,78 \%$, sedangkan sisanya $27,22 \%$ dijelaskan oleh variabel lain yang tidak masuk dalam model. Dari hasil estimasi di atas menunjukkan bahwa tanda koefisien regresi harga udang domestik tandanya negatif, harga ekspor udang segar di pasar Jepang pada tahun sebelumnya, nilai tukar rupiah terhadap US dollar, dan pendapatan domestik bruto Jepang pada tahun sebelumnya tandanya positif. Hal ini sudah sesuai dengan harapan teori. 
Tabel 3. Nilai Koefisien atau Elastisitas Permintaan Ekspor terhadap Variabel Penjelas

\begin{tabular}{llc}
\hline \multirow{2}{*}{ Variabel } & \multicolumn{2}{c}{ Nilai Elastisitas } \\
\cline { 2 - 3 } & Jangka Pendek & Jangka Panjang \\
\hline$P U D_{t}$ & $-0,235202$ & $-0,398471$ \\
$P X T U J_{t-1}$ & 0,008831 & 0,010348 \\
VQUD $_{t-1}$ & 0,077561 & 0,320957 \\
$G D P J_{t-1}$ & 0,576129 & 0,018493 \\
$N T_{t}$ & 0,678472 & 0,365908 \\
VXUSJ $_{t-1}$ & 0,164942 & 0,310895 \\
\hline
\end{tabular}

Dengan memperhatikan nilai statistik $D W=1,879494$ dan hasil uji $L M$ terlihat bahwa disturbance term error dari VXUSJ tidak mengalami autokorelasi. Secara bersama-sama variabel $P U D_{t}$, $P X U S J_{t-1}, \quad V Q U D_{t-1}, \quad N T_{t}, G D P J_{t-1}$, dan $V X U S J_{t-1}$ signifikan secara statistik mempengaruhi $\quad V X U S J_{t}$ di mana F-statistik = 7.256815. Dengan kata lain, residual regresi ko integrasi pada model tersebut stasioner. Dengan demikian, residual kointegrasi atau kesalahan ketidakseimbangan stasioner atau I(0).

Secara parsial diperoleh hasil bahwa nilai tukar rupiah terhadap US dollar $\left(N T_{t}\right)$ berpengaruh secara signifikan pada $\alpha=1 \%$ terhadap ekspor udang segar ke Jepang $\left(V X U S J_{t}\right)$ ceteris paribus, dan pendapatan produk domestik bruto Jepang tahun sebelumnya berpengaruh secara signifikan pada $\alpha=5 \%$ terhadap ekspor udang segar ke Jepang $\left(V X U S J_{t}\right)$, ceteris paribus. Nilai tukar rupiah terhadap US dollar, mem- punyai pengaruh positif terhadap ekspor udang segar dengan koefisien 0,6333, tetapi responnya tidak elastis (inelastic) terhadap ekspor udang segar ke Jepang, ceteris paribus. Dengan kata lain, apabila nilai tukar rupiah terhadap US dollar terdepresiasi sebesar 1\% maka ekspor udang segar ke Jepang naik sebesar $0,6785 \%$, ceteris paribus. Hal yang sama terjadi pada pendapatan bruto Jepang tahun sebelumnya mempunyai pengaruh positif terhadap ekspor udang segar dengan koefisien 0.5761 dan responnya tidak elastis (inelastic) terhadap ekspor udang segar ke Jepang, ceteris paribus. Dengan kata lain, apabila pendapatan domestik bruto Jepang naik sebesar $1 \%$ maka ekspor udang segar ke Jepang naik sebesar $0,5761 \%$, ceteris paribus (Tabel 2). Dari hasil estimasi di atas menunjukkan bahwa variabel-variabel penelitian lolos dari uji diagnosis dan koefisien $E C T_{t-1}$ signifikan secara statistik 
dan tanda koefisien regresi sesuai dengan yang diharapkan secara teori.

Hasil estimasi dari regresi kointegrasi menunjukkan bahwa variabelvariabel harga udang domestik $\left(P \cup D_{t}\right)$, lag nilai produk domestik bruto Jepang $\left(G D P J_{t-1}\right)$, dan nilai tukar rupiah terhadap US dollar $\left(N T_{t}\right)$ mempunyai hubungan jangka panjang. Dengan demikian dapat dikatakan bahwa variabel yang mampu menjelaskan varian ekspor udang segar ke Jepang $\left(V X U S J_{t}\right)$ adalah harga udang domestik $\left(P \cup D_{t}\right)$, lag nilai produk domestik brutto Jepang $\left(G D P J_{t-1}\right)$, dan nilai tukar rupiah terhadap US dollar $\left(N T_{t}\right)$.

\section{Permintaan Ekspor Komoditas Udang Segar oleh Amerika Serikat}

Hasil estimasi Error Correction Mechanism (ECM) dari ekspor komoditas udang segar ke Amerika Serikat $\left(\right.$ VXUSA $\left.A_{t}\right)$ selama periode 1989-2017 sebagai fungsi dari lag harga udang domestik $\left(P \cup D_{t-1}\right)$, harga ekspor udang segar ke Amerika Serikat $\left(P X U S A_{t}\right)$, nilai tukar rupiah terhadap US dollar $\left(N T_{t}\right)$, produksi udang domestik $\left(V Q U D_{t}\right)$, produk domestik bruto Amerika Serikat $\left(G D P A_{t}\right)$, dan lag ekspor udang segar ke Amerika Serikat $\left(V X \cup S A_{t-1}\right)$. Dengan demikian, persamaan permintaan ekspor udang segar Indonesia di pasar Amerika Serikat dalam jangka panjang dapat dirumuskan sebagai berikut:

$$
\begin{aligned}
\operatorname{LNVXUSA}_{t}= & b_{0}+b_{1} L N P U D_{t+} b_{2} L N P X U S A_{t} \\
& +b_{3} L N V X U S A_{t-1}+b_{4} L N V Q U D_{t} \\
& +b_{5} L N N T_{t}+b_{6} L N G D P A_{t}+e_{t}
\end{aligned}
$$

Persamaan untuk estimasi model dalam jangka pendek digunakan model error correction sebagai berikut:

$$
\begin{aligned}
\Delta L N V X U S A_{t} & =b_{0}+b_{1} \Delta L N P U D_{t}+ \\
& b_{2} \Delta L N P X U S A_{t}+ \\
& b_{3} \Delta L N V X U S A_{t-1}+ \\
& b_{4} \Delta L N V Q U D_{t}+b_{5} \Delta L N N T_{t}+ \\
& b_{6} \Delta L N G D P A_{t}+b_{7} E C T+e_{t}
\end{aligned}
$$

di mana $b_{1}<0, b_{2}>0, b_{3}>0, b_{4}>0, b_{5}>0, b_{6}>$ $0, b_{7}<0$

Keterangan:

LNVXUSA $_{t}$ : Log volume ekspor udangsegar Indonesia di pasar ASpada tahun ke-t $(\mathrm{kg})$

LNPUDt : Log harga udang domestik Indonesia pada tahun $\mathrm{t}(\mathrm{Rp} / \mathrm{kg})$

LNPXUSA $_{t}$ : Log harga ekspor udang segar Indonesia di pasar AS pada tahun $\mathrm{t}$ (US Dollar/kg)

LNVXUSA $A_{t-1}$ : Log volume ekspor udang segar Indonesia di pasar AS pada tahun sebelumnya $\mathrm{t}-1(\mathrm{~kg})$

LNVQUD $_{t}$ : Log produksi udang domestik Indonesia pada tahun $\mathrm{t}(\mathrm{kg})$

LNNT $_{t} \quad$ : Log nilai tukar riil rupiah terhadap US dollar (Rp/US\$)

LNGDPA $_{t} \quad$ : Log pendapatan nasional Amerika Serikat (US\$ Miliar)

Sebelum dilakukan analisis terhadap persamaan yang digunakan dalam model, terlebih dahulu seluruh data yang digunakan harus berada pada kondisi yang stasioner. Hasil pengujian stasioner terhadap peubah-peubah yang digunakan dalam kajian ini tertera pada Tabel 4.

Hasil uji akar-akar unit menunjukkan bahwa pada kondisi level hampir semua variabel belum stasioner, baik dengan pendekatan Augmented Dickey Fuller ( $A D F$ ) maupun Phillip-Peron (PP), kecuali variabel $L N P U D_{t}$ dan $L N P X U S A_{t}$. 
Tabel 4. Hasil Uji Akar-akar Unit

\begin{tabular}{|c|c|c|c|c|}
\hline \multirow[t]{2}{*}{ Peubah/ Variabel } & \multicolumn{2}{|c|}{ Tingkat/Level } & \multicolumn{2}{|c|}{$\begin{array}{c}\text { Perbedaan Pertama/ First } \\
\text { Difference }\end{array}$} \\
\hline & ADF & PP & ADF & PP \\
\hline$L N V X U S A_{t}$ & 0,9081 & 0,9330 & $0,0005^{\star \star *}$ & $0,0005^{\star \star \star}$ \\
\hline$L_{N P U D_{t}}$ & 0,6382 & $0,0066^{\star * *}$ & $0,0000^{\star * *}$ & $0,0001^{* * *}$ \\
\hline$L N P X U S A_{t}$ & $0,0630^{*}$ & $0,0565^{\star}$ & $0,0074^{\star * *}$ & $0,0000^{\star * *}$ \\
\hline$L N V Q U D_{t}$ & 0,8626 & 0,9459 & $0,0000^{\star * *}$ & $0,0000^{\star * *}$ \\
\hline$L N G D P A_{t}$ & 0,1849 & 0,1849 & $0,0261^{* *}$ & $0,0274^{\star *}$ \\
\hline$L N N T_{t}$ & 0,1955 & 0,2096 & $0,0000^{* * *}$ & $0,0000^{\star * *}$ \\
\hline$L N V X U S A_{t-1}$ & 0,8948 & 0,8912 & $0,0007^{\star \star \star}$ & $0,0007^{\star * *}$ \\
\hline
\end{tabular}

Tabel 5. Hasil Pendugaan Permintaan Ekspor Udang Segar di Pasar Amerika Serikat

\begin{tabular}{|c|c|c|c|c|}
\hline Variabel & & Koefisien Regresi & Simpangan Baku & t-statistik \\
\hline Konstanta & & 0,016674 & 0,087696 & 0,190138 \\
\hline$D\left(L N P \cup D_{t}\right)$ & & $-0,064454$ & 0,124046 & $-0,519598$ \\
\hline$D\left(L N P X U S A_{t}\right)$ & & $0,039641^{*}$ & 0,022093 & $1,794258^{\star}$ \\
\hline$D\left(L N V Q U D_{t}\right)$ & & 0,072028 & 0,251506 & 0,286386 \\
\hline$D\left(G D P A_{t}\right)$ & & $0,122201^{*}$ & 2,845685 & 0,042943 \\
\hline$D\left(L N N T_{t}\right)$ & & 0,315585 & 0,277961 & 1,135360 \\
\hline$D\left(L N V X \cup S A_{t-1}\right)$ & & $-0,309116$ & 0,360254 & $-0,858050$ \\
\hline$E C T_{t-1}$ & & $-0,996445^{* *}$ & 0,440323 & $-2,262983^{* *}$ \\
\hline $\mathrm{R}^{2}$ & 0,654096 & $6 \operatorname{LM}(2)$ & 2,935376 & $($ prob, $=0,2305)$ \\
\hline $\mathrm{R}^{2}$-adjusted & 0,626658 & 8 White & 17,71484 & $($ prob, $=0,0133)$ \\
\hline F-statistic & 5,132648 & $8 \mathrm{ARCH}$ & 0,401213 & $($ prob, $=0,5265)$ \\
\hline F-prob. & 0,002082 & & & \\
\hline DW & 1,951293 & & & \\
\hline
\end{tabular}

Akan tetapi, semua peubah telah stasioner pada kondisi first difference dengan tingkat kesalahan $1 \%$, baik dengan pendekatan ADF maupun PP. Dengan demikian dapat disimpulkan bahwa semua peubah ini dapat digunakan lebih lanjut ke persamaan permintaan ekspor udang segar Indonesia di pasar AS dengan menggunakan pendekatan Error Correction Model (ECM).

Hasil estimasi OLS ditunjukkan pada Tabel 5, di mana permintaan eks- 
por udang segar oleh Amerika Serikat secara signifikan dipengaruhi harga ekspor udang segar ke Amerika Serika $\left(P X \cup S A_{t}\right)$ dengan level signifikan $\alpha=10 \%$. Sementara itu, harga udang domestik $\left(P U D_{t}\right)$, jumlah produksi udang domestik $\left(V Q U D_{t}\right)$, dan nilai tukar rupiah terhadap US dollar $\left(N T_{t}\right)$, tidak signifikan.

Berdasarkan hasil pengujian asumsi klasik maka model ekspor yang dibangun dapat digunakan untuk mendapatkan hasil regresi yang efisien dan tidak bias. Dari Tabel 5, diperoleh hasil bahwa $R^{2}=0,6541$ yang menunjukkan bahwa variabel bebas mampu menjelaskan variansi dari variabel terkait sebesar $65,41 \%$, sedangkan sisanya $34.59 \%$ dijelaskan oleh variabel lain yang tidak masuk dalam model. Dari hasil estimasi di atas menunjukkan bahwa tanda seluruh koefisien regresi tandanya sudah sesuai dengan harapan teori.

Dengan memperhatikan nilai statistik $\mathrm{DW}=1,951293$ terlihat bahwa disturbance term error dari $\left(V X \cup S A_{t}\right)$ tidak autokorelasi sehingga tidak terjadi spurious regression. Secara bersamasama variabel $P U D_{t}, P X U S A_{t}, \quad N T_{t}$, $G D P A_{t}$, dan $V X U S A_{t-1}$, signifikan secara statistik mempengaruhi $\left(V X U S A_{t}\right)$ di mana $F$-statistik $=5,132648$. Dengan kata lain, residual regresi ko integrasi pada model tersebut stasioner. Dengan demikian, residual ko integrasi atau kesalahan ketidakseimbangan stasioner atau I(0).

Secara parsial diperoleh hasil bahwa harga ekspor udang segar ke Amerika Serikat berpengaruh secara signifikan pada $\alpha=10 \%$ ceteris paribus, dan sesuai secara teori, dan produk domestik bruto Amerika Serikat berpengaruh secara signifikan pada $\alpha=10 \%$ ceteris paribus, dan sesuai secara teori. Nilai koefisien pada harga ekspor udang segar ke Amerika Serikat sebesar 0,0396 menunjukkan bahwa kenaikan harga ekspor udang segar ke Amerika Serikat sebesar 1 (satu) persen maka akan meningkatkan ekspor udang segar ke Amerika Serikat sebesar 0,0396 persen, ceteris paribus. Berdasarkan hasil pengujian asumsi klasik maka model ekspor yang dibangun dapat digunakan untuk mendapatkan hasil regresi yang efisien dan tidak bias. Untuk itu, dari hasil estimasi di atas menunjukkan bahwa variabel-variabel penelitian lolos dari uji diagnosis dan koefisien $E C T_{t-1}$ signifikan secara statistik dan tanda koefisien regresi sesuai dengan yang diharapkan secara teori.

Metode estimasi ECM juga dapat memberikan informasi mengenai korelasi perubahan variabel independen terhadap variabel dependen atau elastisitas ekspor udang segar terhadap variabel bebasnya dalam jangka panjang. Nilai elastisitas tersebut dapat dilihat dari 
Tabel 6. Nilai Koefisien atau Elastisitas Permintaan Ekspor Terhadap Variabel Penjelas

\begin{tabular}{lcc}
\hline \multirow{2}{*}{ Variabel } & \multicolumn{2}{c}{ Nilai Elastisitas } \\
\cline { 2 - 3 } & Jangka Pendek & Jangka Panjang \\
\hline$P U D_{t}$ & $-0,064454$ & $-0,132800$ \\
$P X U S A_{t}$ & 0,039641 & 0,046456 \\
$V Q U D_{t}$ & 0,072028 & 0,189833 \\
$G D P A_{t}$ & 0,122201 & 0,784379 \\
$N T_{t}$ & 0,315585 & 0,189175 \\
$V X U S A_{t-1}$ & $-0,309116$ & 0,725044 \\
\hline
\end{tabular}

koefisien regresi pada jangka pendek dan jangka panjang seperti yang ditunjukkan pada Tabel 6.

Tabel 6 menunjukkan bahwa besarnya elastisitas pada jangka panjang lebih besar dibandingkan dengan jangka pendeknya, kecuali peubah nilai tukar Rp/US\$. Nilai elastisitas yang terbesar dimiliki oleh nilai tukar rupiah terhadap dollar AS (NT), volume ekspor, dan GDP AS yang masing-masing sebesar 0,3156 ; 0,3091 ; dan 0,1222 . Hal ini mengindikasikan bahwa faktor yang dominan mempengaruhi permintaan ekspor udang segar di AS dalam jangka pendek adalah nilai tukar Rp/US\$. Pada jangka panjang, faktor yang pengaruhnya paling besar adalah GDP AS. Sementara itu, elastisitas peubah harga ekspor udang segar di pasar AS memiliki nilai koefisien yang rendah, baik pada jangka pendek maupun pada jangka panjang. Hal ini berarti bahwa fluktuasi harga ekspor yang ditawarkan pasar AS relatif tidak memberikan pengaruh bagi permintaan udang segar Indonesia.

\section{Permintaan Ekspor Komoditas Udang Segar oleh Uni Eropa}

Hasil estimasi Error Correction Mechanism (ECM) dari permintaan ekspor produk udang segar oleh Uni Eropa $\left(V X U S E_{t}\right)$ selama periode 19892017 sebagai fungsi dari harga udang domestik $\left(P U D_{t}\right)$, harga ekspor udang segar ke Eropa $\left(P X \cup S E_{t}\right)$, produksi udang domestik $\left(V Q U D_{t}\right)$, nilai tukar rupiah terhadap US dollar $\left(N T_{t}\right)$, dan lag ekspor udang segar ke Eropa $\left(V_{X} \cup S E_{t-1}\right)$. Dengan demikian, persamaan permintaan ekspor udang segar Indonesia di pasar Uni Eropa dalam jangka panjang dapat dirumuskan sebagai berikut:

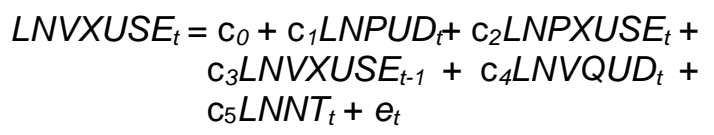
$\mathrm{c}_{3} L N V X U S E_{t-1}+\mathrm{c}_{4} L N V Q U D_{t}+$ $\mathrm{C}_{5} L N N T_{t}+e_{t}$ 
Persamaan untuk estimasi model dalam jangka pendek digunakan model error correction sebagai berikut:

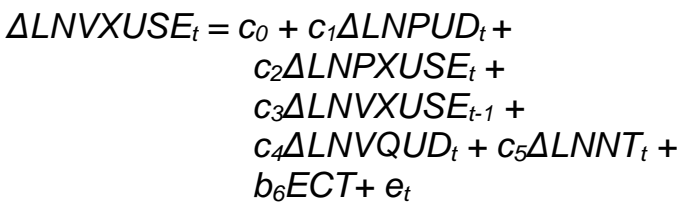

di mana $c_{1}<0, c_{2}>0, c_{3}>0, c_{4}>0, c_{5}>0, b_{6}<$ 0

Keterangan:

LNVXUSE $_{t} \quad$ : Log volume ekspor udang segar Indonesia di pasar Uni Eropa pada tahun ke-t $(\mathrm{kg})$

LNPUD $_{t} \quad$ : Log harga udang domestik Indonesia pada tahun $\mathrm{t}(\mathrm{Rp} / \mathrm{kg})$

LNPXUSE $_{t}$ : Log harga ekspor udang segar Indonesia di pasar Uni Eropa pada tahun $\mathrm{t}(\mathrm{US} \$ / \mathrm{kg})$

LNVXUSE $_{t-1}$ : Log volume ekspor udang segar Indonesia di pasar Uni Eropa pada tahun sebelumnya t-1 $(\mathrm{kg})$

LNVQUD $_{t} \quad$ : Log produksi udang domestik Indonesia pada tahun $\mathrm{t}(\mathrm{kg})$

LNNT $_{t} \quad$ : Log nilai tukar riil rupiah terhadap US dollar (Rp/US\$)

Sebelum dilakukan analisis terhadap persamaan yang digunakan dalam model, terlebih dahulu seluruh data yang digunakan harus berada pada kondisi yang stasioner. Hasil pengujian stasioner terhadap peubah-peubah yang digunakan dalam kajian ini tertera pada Tabel 7.
Hasil uji akar-akar unit menunjukkan bahwa pada kondisi level hampir semua variabel belum stasioner, baik dengan pendekatan Augmented Dickey Fuller ( $A D F)$ maupun Phillip-Peron (PP), kecuali variabel $L N P U D_{t}, L N P X U S E_{t}$, dan $L N V X U S E_{t-1 .}$ Akan tetapi, semua peubah telah stasioner pada kondisi first difference dengan tingkat kesalahan $1 \%$, baik dengan pendekatan $A D F$ maupun $P P$. Dengan demikian dapat disimpulkan bahwa semua peubah ini dapat digunakan lebih lanjut ke persamaan permintaan ekspor udang segar Indonesia di pasar Uni Eropa dengan menggunakan pendekatan Error Correction Model (ECM).

Hasil estimasi OLS ditunjukkan pada Tabel 8, di mana permintaan ekspor udang segar oleh Uni Eropa secara signifikan dipengaruhi lag ekspor udang segar ke Eropa ( $\left.V X U S E_{t-1}\right)$ dengan level signifikan $\alpha=1 \%$. Sedangkan harga udang domestik, harga ekspor udang

Tabel 7. Hasil Uji Akar-akar Unit

\begin{tabular}{lcccc}
\hline \multirow{2}{*}{$\begin{array}{r}\text { Peubah/ } \\
\text { Variabel }\end{array}$} & \multicolumn{2}{c}{ Tingkat/Level } & \multicolumn{2}{c}{$\begin{array}{c}\text { Perbedaan Pertama/ First } \\
\text { Difference }\end{array}$} \\
\cline { 2 - 5 } & ADF & PP & ADF & PP \\
\hline LNVXUSE $_{t}$ & $0,0004^{* * *}$ & $0,0004^{* * *}$ & $0,0000^{* * *}$ & $0,0001^{* * *}$ \\
LNPUD $_{t}$ & $0,0568^{*}$ & $0,0527^{*}$ & $0,0000^{* * *}$ & $0,0000^{* * *}$ \\
LNPXUSE $_{t}$ & 0,2018 & 0,2054 & $0,0000^{* * *}$ & $0,0000^{* * *}$ \\
LNVQUD $_{t}$ & 0,8626 & 0,9459 & $0,0000^{* * *}$ & $0,0000^{* * *}$ \\
LNNT $_{t}$ & 0,1955 & 0,2096 & $0,0000^{* * *}$ & $0,0000^{* * *}$ \\
LNVXUSE $_{t-1}$ & $0,0005^{* * *}$ & $0,0005^{* * *}$ & $0,0000^{* * *}$ & $0,0001^{* * *}$ \\
\hline Keterangan: & ${ }^{* *},{ }^{* * *}=$ & Stasioner Nyata pada taraf $\alpha=10 \%, \alpha=5 \%$, dan $\alpha=1 \%$
\end{tabular}


Tabel 8. Hasil Estimasi Permintaan Ekspor Udang Segar di Pasar Uni Eropa

\begin{tabular}{|c|c|c|c|}
\hline Variabel & Koefisien Regresi & Simpangan Baku & t-statistik \\
\hline Konstanta & 0,180832 & 0,324257 & 0,557682 \\
\hline$D\left(L N P \cup D_{t}\right)$ & $-5,250929^{* *}$ & 1,909212 & $-2,750312$ \\
\hline$D\left(L N P X U S E_{t-}\right)$ & 0,522166 & 0,666900 & 0,782974 \\
\hline$D\left(L N V Q U D_{t}\right)$ & $4,443969^{\star \star \star}$ & 1,473274 & 3,016389 \\
\hline$D\left(L N N T_{t}\right)$ & 0,762016 & 1,299993 & 0,586169 \\
\hline$D\left(L N V X U S E_{t-1}\right)$ & 0,007819 & 0,152861 & 0,051150 \\
\hline$E C T_{t-1}$ & $-0,999496^{\star * *}$ & 0,270186 & $-3,699294$ \\
\hline $\mathrm{R}^{2}$ & 0,730013LM(2) & 3,970297 & $($ prob $,=0,1374)$ \\
\hline $\mathrm{R}^{2-a d j u s t e d}$ & 0,649017Breusch-Pagan & 5,833879 & $($ prob $,=0,4421)$ \\
\hline F-statistic & $9,012931 \mathrm{ARCH}$ & 0,009431 & $($ prob $,=0,9226)$ \\
\hline F-prob, & 0,000077 Jarque-Bera & 0,724213 & $($ prob $,=0,6962)$ \\
\hline DW & 1,744128 & & \\
\hline
\end{tabular}

segar ke Eropa, dan nilai tukar rupiah terhadap US dollar tidak signifikan.

Berdasarkan hasil pengujian asumsi klasik maka model ekspor yang dibangun dapat digunakan untuk mendapatkan hasil regresi yang efisien dan tidak bias. Nilai $R^{2}=0,7300$ yang menunjukkan bahwa variabel bebas mampu menjelaskan variansi dari variabel terkait sebesar $73 \%$, sedangkan sisanya $27 \%$ dijelaskan oleh variabel lain yang tidak masuk dalam model. Dari hasil estimasi di atas menunjukkan bahwa tanda seluruh koefisien regresi tandanya sudah sesuai dengan harapan teori.

Dengan memperhatikan nilai statistik DW $=1,7441$ dan hasil uji LM terlihat bahwa disturbance term error dari $V X U S E_{\mathrm{t}}$ tidak autokorelasi sehingga tidak terjadi spurious regression. Secara bersama-sama variabel $P U D_{t}, P X U S E_{t}$, $V Q U D_{t}, \quad N T_{t}$, dan $V X U S E_{t-1}$ signifikan secara statistik mempengaruhi $V X U S E_{t}$ di mana $F$-statistik $=9,012931$. Dengan kata lain, residual regresi ko integrasi pada model tersebut stasioner. Dengan demikian, residual ko integrasi atau kesalahan ketidakseimbangan stasioner atau I(0).Secara parsial diperoleh hasil bahwa harga udang segar domestik berpengaruh secara signifikan pada $\alpha=5 \%$, ceteris paribus, dan sesuai secara teori. Produksi udang berpengaruh secara nyata pada $\alpha=1 \%$ ceteris paribus dan sesuai secara teori. Hasil estimasi juga menunjukkan bahwa variabel-variabel penelitian lolos dari uji diagnosis dan koefisien $E C T_{t-1}$ signifikan secara statistik dan koefisien regresi bertanda negatif 
Tabel 9. Nilai Koefisien atau Elastisitas Permintaan Ekspor terhadap Variabel Penjelas

\begin{tabular}{cc}
\hline \multicolumn{2}{c}{ Nilai Elastisitas } \\
\hline Jangka Pendek & Jangka Panjang \\
\hline$-5,250929$ & $-5,326067$ \\
0,522166 & 0,158486 \\
4,443969 & 2,243760 \\
0,762016 & 1,551032 \\
0,007819 & 0,091070 \\
\hline
\end{tabular}

sesuai dengan yang diharapkan secara teori.

Metode estimasi ECM juga dapat memberikan informasi mengenai korelasi perubahan variabel independen terhadap variabel dependen atau elastisitas ekspor udang segar terhadap variabel bebasnya dalam jangka panjang. Nilai elastisitas tersebut dapat dilihat dari koefisien regresi pada jangka pendek dan jangka panjang seperti yang ditunjukkan pada Tabel 9.

Pada Tabel 9, menunjukkan bahwa besarnya elastisitas pada jangka panjang lebih besar dibandingkan dengan jangka pendeknya, kecuali peubah harga ekspor dan produksi udang segar. Nilai elastisitas yang terbesar dimiliki oleh harga udang domestik, produksi udang, dan nilai tukar rupiah terhadap dollar AS yang masing-masing sebesar 5,2509; 4,4434; dan 0,7620. Hal ini mengindikasikan bahwa faktor yang dominan mempengaruhi ekspor udang segar ke Eropa dalam jangka pendek dan jangka panjang adalah harga udang domestik. Sementara itu, elastisitas peubah volume ekspor udang segar di pasar Eropa memiliki nilai koefisien yang rendah, baik pada jangka pendek maupun pada jangka panjang. Hal ini berarti bahwa permintaan ekspor sebelumnya relatif tidak memberikan pengaruh bagi permintaan ekspor udang segar Indonesia di pasar Eropa.

\section{SIMPULAN DAN SARAN}

\section{Simpulan}

Model Permintaan Ekspor Udang Segar Indonesia memberikan hasil cukup baik (Model Ekonometrika) dilihat dari segi ekonomi maupun statistik. Peubah yang masuk dalam persamaan di antaranya adalah variabel harga domestik, harga dunia, memenuhi kriteria ekonomi. Adapun model untuk masing-masing komoditas adalah sebagai berikut: Pendugaan fungsi permintaan ekspor udang segar oleh pasar (Jepang, Amerika Serikat, dan Uni 
Eropa) dipengaruhi harga udang domestik, harga ekspor udang ke negara tujuan, lag ekspor udang segar ke negara tujuan, nilai produk domestik bruto negara tujuan, dan produksi udang domestik. Namun untuk harga ekspor ke Jepang dan Uni Eropa tidak signifikan, hal ini menunjukkan pasar udang segar ke Jepang dan Uni Eropa sudah mengalami kejenuhan.

\section{Saran}

Berdasarkan hasil kajian dan analisis serta kesimpulan di atas, hal-hal yang dapat disarankan adalah: 1) Pemerintah perlu melakukan pencarian pasar baru untuk meningkatkan ekspor udang segar karena berdasarkan analisis di atas pasar udang segar ke Jepang, Amerika Serikat, dan Eropa sudah mengalami kejenuhan; 2) Mendorong upaya pengembangan diversifikasi pasar tujuan ekspor dan juga jenis produk berbasis komoditas unggulan perikanan utama.

\section{PERSANTUNAN}

Penulis mengucapkan terima kasih kepada Balai Besar Riset Sosial Ekonomi Kelautan dan Perikanan yang telah memfasilitasi pelaksanaan kegiatan penelitian untuk menghasilkan karya tulis ilmiah ini. Penulis juga mengucapkan banyak terima kasih kepada Badan Karantina Ikan, Pengendalian Mutu dan Keamanan Hasil Perikanan (BKIPM),
Kementerian Kelautan dan Perikanan yang telah banyak membantu terkait dengan akses untuk dapat menggunakan data bagi penelitian ini.

\section{DAFTAR PUSTAKA}

Bass, Alexander. 2018. "Does Electricity Supply Matter for Economic Growth in Russia: A Vector Error Correction Approach." International Journal of Energy Economics and Policy 8(5):313-18.

BPS. 2019. Data Operasional BPS Tahun 2019. Jakarta (ID): Badan Pusat Statistik.

Falcetti, Elisabetta, dan Luis Catão. 1999. "Determinants of Argentina's External Trade." IMF Working Papers 99(121):1.

FAO. 2018. "Globefish Highlights A Quarterly Update on World Seafood Markets."

Fatimah, Siti Sahatul, Sri Marwanti, dan Suprapti Supardi. 2020. "Kinerja ekspor udang Indonesia di Amerika Serikat tahun 2009-2017: Pendekatan Model Constant Market Share (CMS)." Jurnal Sosial Ekonomi Kelautan dan Perikanan 15(1):57.

Granger, Clive W. J., dan Paul Newbold. 1974. "Spurious regressions in econometrics." Journal of econometrics 2(2):111-20. 
Hidayati, Sri, Dwidjono Hadi Darwanto, dan Masyhuri. 2017. Kinerja Ekspor Tuna Indonesia: Kajian Mengenai Daya Saing \& Faktor yang Mempengaruhi terhadap Ekspor Tuna Indonesia di Pasar Jepang, Amerika Serikat \& Korea Selatan. Yogyakarta (ID): Penerbit Andi.

Ihsan, dan Mustamin Tajuddin. 2019.

"Produksi udang dan pola musim penangkapannya di perairan Kabupaten Pangkep." JOURNAL OF INDONESIAN TROPICAL FISHERIES (JOINT-FISH) : Jurnal Akuakultur, Teknologi Dan Manajemen Perikanan Tangkap, IImu Kelautan 2(1):100-110.

KKP. 2020. "Dashboard Statistik Kelautan dan Perikanan." Diambil (https://statistik.kkp.go.id/home.ph $p ? m=$ total $\& \mathrm{i}=2 \#$ panel-footer $)$.

Luhur, Estu Sri, Asnawi, dan Siti Hajar Suryawati. 2020. "Respon penawaran udang Indonesia: Pendekatan ECM." in Prosiding Seminar Nasional Riset dan Kebijakan Sosial Ekonomi Kelautan dan Perikanan. Jakarta (ID): AMAFRAD Press.

Nyatanga, 2017.

"Zimbabwe's Trade Performance Under Alternative Trade Policy Regimes." Foreign Trade Review 52(2):90-105.
Permatasari, H. 2019. "Pengaruh Kebijakan GSP (Generalized System of Preferences) terhadap Daya Saing Ekspor Udang Indonesia ke Uni Eropa [Tesis]." Universitas Brawijaya.

Pudyastuti, Puput Ayu, Herman Sambodo, dan Kikin Windhani. 2018. "Analisis Daya Saing Ekspor Komoditas Udang Indonesia di Pasar Eropa Tahun 2008-2016." in Seminar Nasional dan Call for Paper Sustainable Competitive Advantage (SCA) 8. Purwokerto (ID): Fakultas Ekonomi Unsoed.

Putri, Dewi Sartika, Muhammad Irfan Affandi, dan Wuryaningsih Dwi Sayekti. 2020. "Analisis kinerja usaha dan risiko petambak udang vaname pada sistem tradisional dan sistem semi intensif di Kecamatan Labuhan Maringgai Kabupaten Lampung Timur." Jurnal IImu IImu Agribisnis $8(4): 625-32$.

Rahmawati, D. A. Dwi, dan Wahyu Hidayat. 2017. "Analisis Pengaruh Suku Bunga Sertifikat Bank Indonesia dan Jumlah Uang Beredar Terhadap Tingkat Inflasi di Indonesia Periode 2006.12015.12(Pendekatan Error Correction Model)." Jurnal IImu Ekonomi 1(1). 
Rizal, Jose, dan Syahrul Akbar. 2015. "Perbandingan uji stasioner data time series antara metode: Control Chart, Correlogram, akar unit Dickey Fuller, dan derajat integrasi." Jurnal Gradien 11(1).

Rizqy, Alifia Ainun. 2020. "Analisis Daya Saing Produk Ekspor Udang Indonesia di Pasar Internasional [Skripsi]." Universitas Brawijaya.

Susanawati, Susanawati, Jamhari Jamhari, Masyhuri Masyhuri, dan Dwidjono Dwidjono. 2015. “Integrasi Pasar Bawang Merah di Kabupaten Nganjuk (Pendekatan Kointegrasi Engle-Granger)." AGRARIS: Journal of Agribusiness and Rural Development Research $1(1): 43-51$.
Syahputra, Dedy, Abubakar Hamzah, dan Muhammad Nasir. 2017. "Pengaruh Produk Domestik Bruto, Suku Bunga Riil, dan Partisipasi Angkatan Kerja Terhadap Investasi Swasta di Indonesia (Pendekatan Error Correction Model)." JURNAL PERSPEKTIF EKONOMI DARUSSALAM 3(1):1-16.

UN Comtrade. 2020. "United Nations International Trade Statistics Database." Diambil (https://comtrade.un.org/data/).

Widyawati, Sasanti, dan Setyo Tri Wahyudi. 2016. "Determinan pertumbuhan kredit modal kerja perbankan di Indonesia: Pendekatan Error Correction Model (ECM)." Jurnal Keuangan dan Perbankan 20(1).

Yulistiani, Novia Eka. 2019. “Upaya pemerintah Indonesia dalam meningkatkan ekspor komoditas udang ke Eropa.[Skripsi]." Universitas Pasundan. 